\section{Explaining the servitization paradox: a configurational theory and a performance measurement framework}

Explaining the servitization paradox

\author{
Saara A. Brax
}

School of Business and Management, LUT University, Lappeenranta, Finland Armando Calabrese, Nathan Levialdi Ghiron and Luigi Tiburzi University of Rome "Tor Vergata", Rome, Italy, and

Christian Grönroos

Hanken School of Economics, Helsinki, Finland
Received 26 August 2020 Revised 26 February 2021 8 April 2021

Accepted 9 April 2021

\begin{abstract}
Purpose - Previous research reports mixed results regarding the performance impact of servitization in manufacturing firms. To resolve this, the purpose of this paper is to develop a conceptually consistent and comprehensive measurement framework for both dimensions, servitization and its performance effect, and apply in a configurational analysis to reexamine previous evidence, arriving at a configurational theory of the relationship between servitization and firm performance.

Design/methodology/approach - Combining systematic literature review (SLR) and inductive reasoning, the existing indicators for servitization and performance are identified and clustered into groups that adequately represent both dimensions. The dataset is reanalyzed against the resulting framework to identify the configurational patterns and to formulate the theoretical propositions.

Findings - Financial and nonfinancial indicators of servitization and its performance impact are organized into a comprehensive measurement framework grounded on existing research. The subsequent meta-analysis shows that the positive or negative impacts of servitization on performance depend on how firms implement servitization strategies and which performance aspects are examined.

Research limitations/implications - The results explain when servitization can be successful and confirm the existence of the so-called servitization paradox. The meta-analysis identified patterns that explain the previous mixed results, shaping a configurational theory of servitization. Thus, the measurement framework is conceptually robust and has sufficient detail to capture servitization and its performance outcome as it feasibly distinguished between different organizational configurations.

Originality/value - The framework provides a comprehensive portfolio of indicators for both managers and scholars to measure servitization intensity and performance. This supports managers of servitizing firms in leading this organizational transformation while avoiding its organizational and financial paradoxes.
\end{abstract}

Keywords Servitization, Servitization level, Firm performance, Measurement, Servitization paradox, Configurational analysis

Paper type Research paper

\section{Introduction}

Servitization, referring to service-based strategies and their growing business implementation in manufacturing and other traditionally product-based industries, has been one of the fastest

(C) Saara A. Brax, Armando Calabrese, Nathan Levialdi Ghiron, Luigi Tiburzi and Christian Grönroos. Published by Emerald Publishing Limited. This article is published under the Creative Commons Attribution (CCBY 4.0) licence. Anyone may reproduce, distribute, translate and create derivative works of this article (for both commercial and non-commercial purposes), subject to full attribution to the original publication and authors. The full terms of this licence may be seen at http://creativecommons. org/licences/by/4.0/legalcode 
IJOPM 41,5

\section{8}

growing research area in operations management for the past 15 years. In 2009, IJOPM published its first special issue on the topic, called "Product-service modes of working operations management implications" (Wilkinson et al., 2009). Since then, the interest on servitization has grown rapidly among researchers and firms. In 2009, a literature review on manufacturers providing services identified 58 relevant research articles (Baines et al., 2009a), and less than a decade later, this number was fourfold (Baines et al., 2017; Brax and Visintin, 2017). The service-based strategies permeated the manufacturing sectors correspondingly. While the datasets differ, a study from 2008 reported that the percentage of manufacturers providing some services was around 30\% (Neely, 2008, p. 108) and a 2017 study as high as 75\% (Crozet and Milet, 2017, p. 4).

This research article sets out to increase theoretical parsimony in the research area, aiming to advance measurement of servitization and to explain its dynamics. Three conceptualizations about the nature of servitization are common: transition, extension and transformation (Brax, 2005, p. 143). Whilst these are not in conflict, denoting their differences will clarify the starting point for theorizing.

(1) When servitization is characterized as transition, the focus is on the firms' positioning in the industry value chain (Holmström et al., 2010; Ziaee Bigdeli et al., 2018b); a servitizing firm typically moves closer toward end-users.

(2) Servitization requires extension of the firms' portfolio of offerings because new service offerings are added (Brax and Jonsson, 2009; Zhou et al., 2020); the services may also replace or re-package the pre-existing product-based value propositions.

(3) Servitization calls for organizational transformation, the shift from product-focused processes, organizational capabilities and culture to one that emphasizes services (Brax, 2005; Gebauer et al., 2012).

Despite the agreement at the conceptual level, the relationship between servitization and its impact on performance still puzzles researchers (Wang et al., 2018; Yan et al., 2019; Lexutt, 2020; Zhou et al., 2020). The servitization-performance relationship is characterised by two paradoxes that threaten successful adoption of servitization in manufacturing firms, the financial and the organizational paradox. The financial paradox contends that when a firm makes considerable investments to build its service offerings, it finds that the extended service business does not generate returns that meet the higher costs of service provision (Gebauer et al., 2005). The organizational paradox shows that when firms slowly increase the amount of services in their portfolio of offerings, their risk of failure increases due to organizational rigidities; the incremental service additions lack momentum to drive the critical organizational reform of capabilities and mindset, i.e. from product-oriented to service-oriented (Brax, 2005).

Empirical research evidence on the relationship between servitization and performance is mixed. Crozet and Millet (2017) find that servitization is beneficial to manufacturers, whereas Benedettini et al. (2015) demonstrate that it can have a negative impact on their performance. Visnjic Kastalli and Van Looy (2013) contend that the servitization-performance relationship is S-shaped, whereas Eggert et al. (2014) find a U-shape. For some factors (e.g. the presence of a separate service business unit), the results are even contradictory (Gebauer and Putz, 2007; Oliva et al., 2012). Making the comparison difficult, these studies define performance and servitization differently.

Do such mixed results reflect a "paradoxical relationship" between servitization and performance? Not necessarily. The mixed findings could also indicate that the different theoretical concepts are incommensurable or less aligned than expected (Lexutt, 2020). Inconsistencies could be rooted in operationalizing the concepts or in different characteristics 
of studied firm populations (Benedettini et al., 2017; Fliess and Lexutt, 2019; Sousa and Da Silveira, 2017; Yan et al., 2019). Thus, if the mixed results are rooted in the dynamics of the two paradoxes, what are the theoretical components that explain and resolve differences between the individual studies? How to translate between the different concepts and firm characteristics, and measure more consistently? These questions represent the remaining tension in the "still-puzzling" relationship between servitization and firm performance, their possible root causes and directions to seek solutions (Zhou et al., 2020, p. 23).

To address the described gaps, this study consists of two parts. The first part develops a multi-layered framework to measure both main dimensions; servitization and its performance impact. To identify the key concepts, constructs and indicators for both dimensions, a bottom-up process mimicking the constant comparison procedure of inductive analysis is designed, and existing servitization literature is systematically processed. This ensures that the synthetized framework is relevant and representative of the servitization research field, accommodating its methodological pluralism. Providing conceptual tools for defining primary constructs serves the needs of quantitative research designs as their proportion increases in the maturing research area.

In the second part, configurational analysis is used to re-analyze the sampled literature against the dimensions of the measurement framework in order to track the various configurations of servitization and firm performance (Forkmann et al., 2017; Kohtamäki et al., 2019; Sjödin et al., 2019; Lexutt, 2020). The possible relationships among the dimensions are investigated, and a set of propositions are formulated that capture the resulting synthesis, a configurational theory of servitization.

The configurational theory is based on propositions that describe three major constellations of servitization and firm performance that fit a S-shaped curve, and thus, a consistent theoretical explanation emerges. The findings thus both validate and elaborate pre-existing theoretical understanding described through the dynamics of the two "servitization paradoxes". In addition, the configurational analysis connects the theory and the mixed results in a mutually re-inforcing relationship, like - put simply - the different slopes fit in the S-shaped curve.

The study proceeds as follows. The theoretical foundation is presented in the next section. Then, the procedure of the SRL is explained and the framework is inductively derived. After that, a meta-analysis of existing literature, using the framework, is performed to clarify the impact of servitization to performance. Implications, limitations and concluding remarks are presented in the last two sections.

\section{Theoretical foundation}

This section explains the basic assumptions and core concepts that constitute the rationale of the research approach. In particular, the section explains the ontological and epistemological aspects of the servitization concept and the scope of performance measurement.

\subsection{Core concepts and basic assumptions}

2.1.1 Servitization and the level of servitization. Origins of the servitization concept and its relationship to other concepts such as product-service systems (PSS), integrated solutions, and complex products and systems (CoPS) are well-documented in pre-existing research (see Rabetino et al., 2018). The concepts above are generalized business model configurations in which physical systems are augmented with service components, and their detailed analysis is outside the scope of the current purpose.

The primary source (Vandermerwe and Rada, 1988) for the term explains servitization as the tendency of firms to add increasingly complex, customer-oriented bundles of goods and

Explaining the servitization paradox 
IJOPM 41,5 services to their pre-existing portfolio of offerings. A more simplified conceptualization sees it as the firm's movement along a continuum ranging from pure manufacturing to pure service provision (Oliva and Kallenberg, 2003). Mathieu (2001b) increased conceptual depth to this view by identifying two dimensions with three stages each, service specificity and organizational intensity, and mapping these into a $3 \times 3$ matrix with nine possible locations that represent a typology of "manufacturing service maneuvers". Mathieu (2001a) also examined target of the service; services can be targeted to serve the physical products sold by the manufacturer (known as services supporting the product; SSP), or they may be directed to support the customers' business processes and needs more comprehensively (services supporting the customer; SSC), thereby including any SSP elements needed.

This paper recognizes servitization as an overarching term for service-oriented strategies (Opresnik and Taisch, 2015, p. 174) and is concerned with the so-called servitization of manufacturing (Neely, 2008); manufacturers adding services to their business. More formally, this paper conceptualizes the servitization of manufacturing as the transformation, whereby manufacturers redefine their business logic to enable product-service offerings (Martinez et al., 2010; Laine et al., 2012; Santamaría et al., 2012).

A basic assumption in the early servitization literature is that increasing the level of servitization has a positive impact on the economic performance of the manufacturing firm (Luoto et al., 2017): services were promoted as providing more stable revenues for manufacturers that suffered from volatile market situations, increasing competition, and decreasing margins. The dominance of case research in the early servitization literature (Rabetino et al., 2018) could explain this, because case research portrays success stories more often than failures (cf., Luoto et al., 2017).

As the research area matures, the cumulating empirical research on servitization unfolds its complexity, casting doubt on simplistic assumptions. The service innovation and development activities required for the competitive move are expected to be costly, but further costs also accrue from increasing internal organizational politics and external collaboration (Mathieu, 2001b). While some firms are able to turn their service manoeuvres into high profits, others suffer from poor performance as suggested by the paradoxes of servitization, i.e. due to misaligned operational processes and consequent high cost of service activities (Brax, 2005; Gebauer et al., 2005). Some firms are "deservitizing", i.e. reducing their commitment toward servitization in order to avoid adverse economic, strategic and operational consequences of unsuccessful implementation (Finne et al., 2013; Benedettini et al., 2017; Kowalkowski et al., 2017a).

Overall, a strong consensus exists for the basic assumption of servitization being a twoway phenomenon: servitization is progressive as the service-related elements increase or strengthen; deservitization is its regressive counterpart, where the relative power of the service elements decrease in favor of the product-oriented business approach (Baines et al., 2020). Due to this progressive/regressive nature, servitization as a phenomenon of interest has the changing property of "level", "degree", "phase", or "intensity" (Calabrese et al., 2019). A recent meta-analysis demonstrates that value constellations are advancing stages rather than mere options (Brax and Visintin, 2017). Despite this, various alternatives to measure and define the level of servitization, as a unit of analysis, have been proposed and implemented without reaching a consensus on the preferred approaches so far.

Servitization is a well-defined concept, although its measurement is not as straightforward as its definition. Calabrese et al. (2019) explain the level of servitization as the extent, degree and/or quantity of service elements added to the total offering of a manufacturing business. The two common indicators to measure servitization level, the number of service types (Benedettini et al., 2015) and the share of revenues from services (Crozet and Milet, 2017) have their merits (Calabrese et al., 2019). Yet, various authors recognize the need for more refined measures to address further elements such as the organizational capabilities needed for the 
transformation. As an example, two of the most widely suggested additional indicators are customer orientation and organizational capabilities (Li et al., 2015; Kowalkowski et al., 2017a; Ambroise et al., 2018a). As a response to these calls, this study systematically examines the servitization literature to trace all relevant indicators of servitization. These indicators are then used together with those related to performance to analyze the relationship between the servitization level and its performance impact.

2.1.2 Performance impact of servitization. There are two alternatives commonly adopted to measure the performance impact of servitization. In the first alternative, the correlation between a certain level or "quantity" of servitization and a number of financial performance indicators, such as revenues and profits, is measured (Visnjic et al., 2016; Crozet and Milet, 2017). The performance impact of servitization is good if this correlation is positive and is negative otherwise. As pointed out by Wang et al. (2018), most of the literature measures the servitization performance in this way. The financial paradox of servitization refers to the case in which a negative correlation occurs (Gebauer et al., 2005).

In the second alternative, which is used less frequently, the performance impact of servitization is regarded as the achievement of a set of holistic goals including financial and nonfinancial performance indicators. In this case, the performance of servitization is also referred to as "servitization success" (Lexutt, 2020). When servitization is measured through financial and nonfinancial performance indicators, measures that are anecdotally associated with its good outcome are included. Often measures such as the effect of servitization on product performance (Lexutt, 2020) or the retention/loyalty of the customers (Ziaee Bigdeli et al., 2018a) are included.

As recommended by Wang et al. (2018) and Lexutt (2020), the framework developed in this study measures the performance impact of servitization through a set of financial and nonfinancial indicators. The measures are all those included in the reviewed servitization studies. On the one hand, these are the most relevant for the servitization community. On the other hand, being employed in the reviewed servitization studies, these measures can be used to carry out the analysis of the successful and unsuccessful configurations.

\subsection{Analyzing the servitization-performance relationship: a configurational approach}

According to configuration theory, superior performance is achieved by the combination of various interdependent attributes such as organizational elements, processes and environmental conditions (Meyer et al., 1993). The configurational approach argues that when fit among these attributes, or "gestalts", is achieved, superior performance results (Venkatraman, 1989a). At its core lies the assumption that it is not the presence or absence of certain elements that leads to success or failure, but their appropriate combination(s) (Venkatraman, 1989b). Thus, the theory considers superior performance as resulting from the holistic combination of different attributes (Drazin and Van De Ven, 1985; Miller, 1986; Ward et al., 1996).

Moreover, the theory allows for the existence of equifinal configurations, namely multiple combinations of attributes leading to the same successful, or unsuccessful, outcome (Meyer et al., 1993; Ragin, 2009). Equifinality is particularly relevant to servitization because it implies that there can be many successful and unsuccessful ways to servitize (Yan et al., 2019; Lexutt, 2020). This means that (1) various combinations of the dimensions of servitization level and performance impact exist and (2) these can be positively or negatively correlated or not at all. Thus, the question as to whether servitization has a positive impact on performance is misplaced. A more informative question is how the different ways of servitizing affect the various performance indicators (Lexutt, 2020). The focus should be on discussing which combinations of the servitization level and performance dimensions are positively correlated and under which circumstances.

Recent analyses use the configurational approach to analyze the prominent factors leading to servitization success (Forkmann et al., 2017; Kohtamäki et al., 2019; Sjödin et al.,
Explaining the servitization paradox 
IJOPM

41,5

\section{2}

2019; Yan et al.,2019; Lexutt, 2020). This study applies configuration theory to investigate the servitization-performance relationship by capturing the multidimensional nature of both concepts (i.e. "within concepts"), servitization and performance and to analyze the various combinations of these concepts and constructs (i.e. "among concepts"). The purpose is to use the concepts and constructs as the building blocks to analyze the servitization-performance relationship, to explain the reason behind contradictory results about the relationship and to address the inconsistency and incompleteness of the previous measures representing the level of servitization or its performance impact.

\subsection{Framework for measuring the servitization-performance relationship}

The framework is designed for measuring servitization and performance at the firm level; thus, in studying their relationship, the unit of analysis is the organization. It has two parts, one for the level of servitization and the other for its performance impacts (Figure 1a). Both parts include multiple measures, which are clustered together according to their semantic similarity (Sánchez and Batet, 2013). Each cluster of measures represents a subdimension of servitization or performance. The clusters are proxies of the firms' progress in servitization and the relevant performance outcomes and thus, allow for the relationship to be investigated as something complex and multidimensional in nature instead of linear and simple. Multidimensionality indicates that different configurations of servitization and performance indicators are likely to exist.

Constructing theories requires organizing the hierarchies and relationships among the terminology used. According to Van de Ven (2007, p. 4), theories are explanations of the relationships among concepts or events, within given boundary conditions. Based on the thorough synthesis by Van De Ven (2007), three common levels of abstraction are used in the framework: (1) theoretical concepts is the most abstract level in which terms are semantically defined by their association to other terms and cannot be observed directly; (2) construct is the middle-range abstraction that addresses the constitutive components for a concept and (3) observable variables or events, here indicators, that specify the operational approach to measure the constructs/concepts.

The bottom layer consists of the indicators, which are the measures of servitization or performance used in pre-existing research and here collected through a systematic literature review. The middle layer clusters analogous indicators together into constructs. Analogous constructs are further grouped into concepts. Concepts create aggregate dimensions for similar constructs; constructs create aggregate dimensions for similar indicators. One concept may be composed of multiple constructs; one construct may be made of multiple indicators and one indicator may be assessed through various multi-item scales. The purpose of concepts and
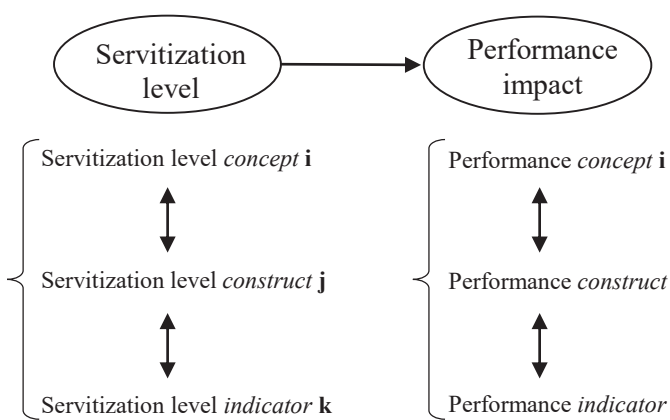

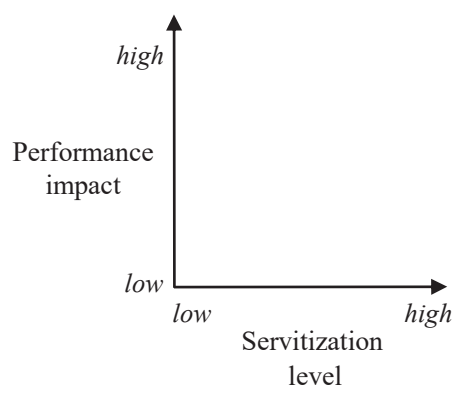

(b)
Figure 1.

Analytical levels of the framework for measuring servitization and its performance impact as multidimensional concepts (a) and investigating their relationship (b)

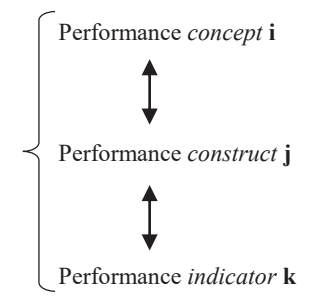

(a) 
constructs is to collect indicators measuring a specific level of servitization or performance aspect. In this way, studies using different indicators for the same underlying aspects can be compared, and the multidimensionality of servitization and its performance impact examined.

This grounded 'bottom-up approach' from indicators to constructs and concepts ensures that the servitization-performance relationship can be studied objectively as the different nuanced aspects of servitization and its performance impacts are recognized and possible inconsistencies resolved through constant comparison. For example, in assessing the performance impact of servitization in a firm, relevant indicators are profits, return on sales and return on investment. Despite being distinct indicators, they can all be regarded as representing the same underlying construct - company financial performance. Recognizing this allows the comparison of studies that measure the performance impact of servitization using any or several of these indicators.

Figure 1 illustrates the structure of the framework. The two continuums, the level of servitization and its performance impact (Figure 1b), are the main or aggregate dimensions that are measured through different indicators, which are grouped in various constructs and concepts. Of course, it is crucial to define the ends of the continuums here. The lowest level of servitization corresponds to a manufacturing firm in which all the servitization indicators collected through the systematic literature review have their lowest value, while at the highest level these indicators reach their maximum. When servitization is at its lowest level, the manufacturer offers the bare minimum level of service to be able to sell its goods and has no intention to offer them in the future nor to nurture the necessary capabilities to do so. Since this lowest level possible may differ depending on the product, the current study uses the term low and high to accommodate all variation. On the other hand, when servitization is at its highest level, the manufacturer offers a wide range of services, and the management is committed to add all the necessary capabilities of service providers without giving up those of manufacturers. The performance impact of a specific servitization level is pictured by an arrow. The performance impact has the same multidimensional structure of the servitization level, making it clear that different servitization levels can influence different performance dimensions. The performance impact varies from servitization because, at least in theory, there is no end point at the high end of the dimension as certain variables may increase without an upper limit. Also, performance impact is typically measured against a reference point; either other firms in the same industry peer group or the past performance of the same firm.

To summarize the terminology used, the framework has two main dimensions: the level of servitization is the independent variable in the theoretical model; performance impact is the dependent variable. The main dimensions are abstract, generalized aggregate concepts and therefore internally complex and multidimensional in nature; thus, each concept represents a subdimension that is considered relevant in order to comprehensively measure the main dimension. Complex and abstract subdimensions have a layered internal structure where constructs connect the abstract level concepts to the applicable level of indicators, whereas conceptually simple subdimensions that address specific measures directly can have flat internal structure.

\section{Methodology}

\subsection{Research design}

Systematic literature review is a widely adopted method in servitization research. Among the first, SRLs were contributions that summarized and structured the knowhow in the field (e.g. Baines et al., 2009b). Important for the pioneering studies was the exhaustive search process as described by Tranfield et al. (2003). More recent SRLs in the area have developed refined and unique styles to perform a rigorous analysis process of the content (Brax and Visintin, 2017; Luoto et al., 2017; Rabetino et al., 2018; Wang et al., 2018).

\section{Explaining the servitization paradox}


IJOPM 41,5

\section{4}

The SRL procedure this research consists of four steps. (1) In sampling, potentially relevant articles are collected from a database. (2) In screening, the relevant articles to design the framework are selected, i.e. those dealing with either the level or performance impact of servitization. (3) In designing, the framework is designed by extracting the servitization level and performance indicators in each article and by recursively clustering them into constructs and concepts (see Figure 1). (4) In analyzing, the framework is used to analyze the servitization-performance relationship in the various articles. The practical procedures for each step combine those utilized in pre-existing research, as discussed below in further detail and presented in Table 1.

\begin{tabular}{|c|c|c|}
\hline Step & Task details & Result \\
\hline \multicolumn{3}{|l|}{ Sampling } \\
\hline \multicolumn{3}{|l|}{ 1. Scope } \\
\hline \multirow{6}{*}{$\begin{array}{l}\text { 1a Formulation } \\
\text { of the query }\end{array}$} & Database: Scopus (date) & \multirow[t]{6}{*}{381 articles } \\
\hline & Search phrase: 'serviti*ation' & \\
\hline & Scope: Title, abstract or keywords & \\
\hline & Limitations: & \\
\hline & $\begin{array}{l}\text { Article or research; Published or accepted- } \\
\text { in-press; Subject area: Business }\end{array}$ & \\
\hline & Language: English & \\
\hline $\begin{array}{l}\text { 1b Gathering } \\
\text { articles }\end{array}$ & $\begin{array}{l}\text { Quality check (exclusion of predatory } \\
\text { publications); availability check and } \\
\text { obtaining full-text documents }\end{array}$ & 366 articles \\
\hline \multicolumn{3}{|l|}{ 2. Screening } \\
\hline \multirow[t]{2}{*}{ 2a Text-mining } & \multirow{2}{*}{$\begin{array}{l}\text { Running a Python-based analysis to extract } \\
\text { the relevant excerpts from the } 366 \text { full-texts }\end{array}$} & Servitization: 101 excerpts \\
\hline & & Performance: 108 excerpts \\
\hline $2 \mathrm{~b}$ Screening & $\begin{array}{l}\text { Manual analysis of the } 209 \text { excerpts to } \\
\text { identify relevant articles }\end{array}$ & 82 articles \\
\hline $\begin{array}{l}2 \mathrm{c} \text { Forming the } \\
\text { final sample }\end{array}$ & $\begin{array}{l}\text { Manual analysis of } 82 \text { full-text articles to } \\
\text { identify articles performing quantitative } \\
\text { analysis that establishes effects between } \\
\text { servitization and performance }\end{array}$ & 36 articles included; 46 articles excluded \\
\hline \multicolumn{3}{|l|}{ Analysis } \\
\hline \multicolumn{3}{|c|}{ 3. Framework design } \\
\hline $\begin{array}{l}\text { 3a Reviewing } \\
\text { and } \\
\text { identification }\end{array}$ & $\begin{array}{l}\text { Manual extraction of the indicators from } 36 \\
\text { full-text articles }\end{array}$ & $\begin{array}{l}88 \text { servitization level indicators; } 44 \\
\text { performance indicators }\end{array}$ \\
\hline $\begin{array}{l}\text { 3b Synthesis } \\
\text { and } \\
\text { organization }\end{array}$ & $\begin{array}{l}\text { Iterative selection and clustering of the } \\
\text { indicators }(88+44) \text {; developing abstraction } \\
\text { levels between indicators, constructs and } \\
\text { concepts }\end{array}$ & The framework \\
\hline \multicolumn{3}{|c|}{ 4. Configurational analysis } \\
\hline $\begin{array}{l}\text { 4a Analysis of } \\
\text { the effects }\end{array}$ & $\begin{array}{l}\text { Analysis of the evidence concerning the } \\
\text { relationship between servitization and its } \\
\text { performance effects }\end{array}$ & $\begin{array}{l}\text { Discussion of the relationships and } \\
\text { their positive or negative impact }\end{array}$ \\
\hline $\begin{array}{l}\text { 4b Shaping } \\
\text { theory }\end{array}$ & $\begin{array}{l}\text { Establishing the higher-level patterns } \\
\text { among the identified relationships by } \\
\text { grouping similar evidence and fitting } \\
\text { elements together }\end{array}$ & $\begin{array}{l}\text { Set of theoretical propositions grounded } \\
\text { on the evidence from pre-existing } \\
\text { servitization research }\end{array}$ \\
\hline
\end{tabular}

Table 1.

Research procedure with four main steps
Database: Scopus (date)

Scope: Title, abstract or keywords

Limitations:

in-press; Subject area: Business

Language: English

publications); availability check and

Running a Python-based analysis to extract

Manual analysis of the 209 excerpts to relevant articles analysis that establishes effects between servitization and performance

Analysis

and

Manual extraction of the indicators from 36 full-text articles

Iterative selection and clustering of the indicators $(88+44)$; developing abstraction concepts

Analysis of the evidence concerning the relationship between servitization and its Establishing the higher-level patterns grouping similar evidence and fitting elements together 


\subsection{Analysis of the literature}

3.2.1 Sampling. In line with Raddats et al. (2019) and Zou et al. (2018), Scopus was chosen as the engine to search for relevant articles. A query was designed to collect all peer-reviewed material with the word "servitization" in the title, abstract or keywords, accommodating for the different spellings (Baines et al., 2017; Calabrese et al., 2019; Fliess and Lexutt, 2019). Three further restrictions were applied to maximize the relevance of the identified publications. First, analogously to Ziaee Bigdeli et al. (2017), the search did not include other common terminology often included in SLRs that aim to maximize the coverage of articles contributing to the industrial services research field (e.g. industrial services, PSS and integrated solutions). This decision is based on the logic that, for example, while PSSs are similar in many respects, not all PSS studies address the transformation related questions at the core of servitization research (Brax and Jonsson, 2009). Yet, the focus of the analysis is to identify and develop measures specific to and representative of servitization. Second, the query was limited to the subject area "Business, Management and Accounting", as the goal is to develop a framework for scholars and practitioners in this area. Third, only publications in English were selected.

The documented Scopus search was performed in November 2019 and identified scholarly research published since 1988. Of the retrieved 381 articles, 366 full-texts could be obtained. One article was excluded due to not being a research article. The remaining articles were not available, and a closer examination discovered that they appeared to be in journals published by so-called "predatory" or opportunistic publishers and thereby were excluded. Thus, the 366 articles form the comprehensive dataset for the screening.

3.2.2 Screening. In this phase, the articles to design the framework were selected. Only peer-reviewed material was included (Roehrich and Lewis, 2014). These were all the empirical articles containing indicators of the level of servitization and/or its performance impact. The decision to exclude irrelevant material was performed on the full-text of the articles rather than on the abstracts. The reason is that the indicators under scrutiny have not yet received a lot of dedicated attention in the servitization literature (Wang et al., 2018; Calabrese et al., 2019). Thus, the odds of finding relevant material in the body of the text rather than in the title/abstracts are high.

The screening of the 366 full-text articles was performed using Python, a programming language that can perform both simple and complex analyses of textual data. Python was used for scanning the article text for the searchwords representing "servitization level" and "servitization performance". Various combinations of keywords were used, and equivalent words from the English dictionary have been added to the search (Baines et al., 2009b). For example, along with "level", also the lemmas "degree", "estimation", "calculation", "appraisal", "progress" and "measure" have been included. This allowed retrieving text semantically identical to "servitization level" and "servitization performance", such as the "degree of servitization" as well as "the measurement of servitization", along with different spellings of the same concepts such as "measuring servitisation". The context of each match was retrieved too, i.e. the 100 words before and after each match, for a total of 200 words.

The excerpts were manually analyzed to select the studies addressing servitization and its performance impact. Excerpts were included such as "we investigate if companies with higher levels of servitization can achieve higher financial results, i.e. generate higher sales, increase market share and improve profit ratios" (Demeter and Szász, 2013, p. 316). The 82 articles selected in this way were examined, and the 36 that contained quantitative indicators, including categorical or ordinal variables, were selected.

3.2.3 Designing. The framework was designed using the 36 articles from the previous step and the structure depicted in Figure 1. Through interpretive comparative analysis, these articles were scrutinised multiple times to extract the indicators. The indicators were inductively clustered into various constructs, subsequently arranged under concepts.
Explaining the servitization paradox 
IJOPM

41,5

Citations of these articles were also examined to identify the original and/or influential sources to clarify the definitions of the indicators.

3.2.4 Analysing. The 36 articles were reexamined in order to perform a configurational analysis of the servitization-performance relationship using the framework; five articles were discarded here due to lacking both servitization and performance measures. The successful and unsuccessful configurations of servitization-performance concepts, constructs and indicators in the remaining 31 articles were compared.

Table 1 summarizes the research procedure and results of each main step. Supplementary material comprehensively catalogs the articles and provides further transparency on details (see the Online Appendix).

\section{The framework to measure servitization and its performance impact}

As outlined in Figure 1, the framework is divided in two parts: one for the level of servitization and one for its performance impact. Each part contains a number of concepts, constructs and indicators (Tables 2 and 3). The purpose of the framework is to provide researchers and managers with a comprehensive tool to measure the level of servitization and its performance impacts.

For servitization level, the framework includes five concepts, nine constructs and 20 indicators. For the performance impact, it has two concepts, eight constructs and 27 indicators. For the level of servitization, the framework includes the most used measures (Calabrese et al., 2019), such as the service portfolio and service revenue as well as other relevant measures necessary to provide a holistic picture. The same applies to the performance impact. Financial and nonfinancial indicators are included as both have been found to be necessary to analyze different aspects of the servitization performance (Wang et al., 2018; Lexutt, 2020).

\section{Configurational analysis and results}

\subsection{Re-analysis of the relationships in the dataset}

The articles in the sample were re-analyzed with the framework presented in Tables 2 and 3, and the evidence concerning the servitization-performance relationship was traced and coded (see Table 4 for results). Table 4 presents the identified concepts and the results concerning their relationships. The details of the indicators and constructs under each concept are reported in the supplementary materials.

The analysis in Table 4 has three purposes. First, it portrays the range of different combinations adopted in earlier research to measure the servitization-performance relationship. This heterogeneity, also identified by Wang et al. (2018), explains inconsistent findings about the servitization-performance relationship. Second, it illustrates how to use the framework to translate past research in a uniform "language" (Kowalkowski et al., 2017b), i.e. the concepts, constructs and indicators of the framework. Third, it shows how this multi-layered framework can be used to analyze heterogeneous indicators referring to the same concepts/constructs. Such analysis provides transparency between the dataset and next section, in which these combinations of concepts (configurations) are used to further the discussion about the servitization-performance relationship (Lexutt, 2020).

\subsection{Configurational analysis and interpretation}

The purpose of the following paragraphs is to analyze the major configurations in Table 4 using the concepts, constructs and indicators in Tables 2 and 3.

There is agreement among scholars that when the servitization level is low, the service portfolio (SP) consists of basic services such as repair and maintenance (i.e. low coverage and 
Conceptual dimension

Construct; indicator and indicator type

Formula/example

Non-financial indicators of servitization level (NFSL)
Explaining the servitization paradox

$\underline{\text { Service portfolio (SP) }}$

Mixed

Service offerings

Coverage of the service portfolio ("scope") Number of service types offered in a generic or context-specific set of known services

Importance of the service offerings ("scale")

Volume of business for each service type in a generic or context-specific set of known services

Service complexity

Sophistication (“depth")

Customization ("variability")

Managerial service orientation (MSO)

Multi-item or single-item Likert scale

Service-oriented management culture

Management awareness of service value

Management awareness of service role in company's business

Management commitment to service strategies

Service-oriented management practice Service-oriented human resource management

Service-oriented physical resource management

Organizational service capabilities (OSC)

Multi-item or single-item Likert scale

Relational service capabilities

Customer orientation

Service co-creation
"Services represent significant business opportunities for our company" "In our business domain, the potential value capture from services remains marginal" (reverse)

Level of sophistication or difficulty of requirements for each service provided, e.g.

Basic/intermediate/advanced service offering (Baines and Lightfoot, 2014)

Customer service; product services and service as a product (Mathieu, 2001b)

The extent of customization, technical configuration and tailoring to satisfy customer needs for each service provided

"Services form the core of the value proposition of our company" "The role services in our business are mainly tactical" (reverse) "We must provide services to sell our products because our competitors do so" (reverse)

"Services have a fundamental role in our business strategy"

"Service development is critical for the future competitiveness of our business"

"Our company actively develops the service skills of our employees"

"Our company enables high performance by providing sufficient resources for the service activities"

"Our services are designed to solve the targeted problem of our customer"

"The starting point for value creation is meeting customer needs with the services we provide"

"Customers are strongly involved in our value creating service activities"

"We collaborate closely with our customers to reach better service outcomes"
Table 2.

Measurement framework for the level 


\section{IJOPM} 41,5
Conceptual dimension

Construct; indicator and indicator type

Service contracting

Service development capabilities

Product and service integration

Service technologies

Service development process

Employee service capabilities

Front-office

Back-office
Formula/example

"Our interactions aim at building long-lasting contract relationships with customers"

"Our interactions with customers are focused on transactions" (reverse)

"Physical products and services are developed side by side"

"Our services, goods and components are designed to be seamlessly integrated"

"Our services make extensive use of advanced technologies"

"We understand the required steps and have the right knowledge to systematically develop the services we offer"

"Cross-functional expertise is engaged in every step of the service development process to ensure long-term success for the outcome"

"Our front-office employees have the required skills and expertise to deliver our services"

"Our back-office employees have the required skills and expertise to deliver our services"

"Our back-office employees have the required skills and expertise to support our front-office operations"

Organizational structure (OS)

Multi-item or single-item Likert scale

Organizational design factors

Dedicated business unit

"Our organization has dedicated business unit(s) for its service provision"

Decentralization of decision-making

"Our organization supports decision-making close to customer interface to ensure efficient service delivery"

"The decision-making processes that concern our service activities are centralized and controlled by top management" (reverse)

Financial servitization level measures (FSL)

$\underline{\text { Service turnover (ST) }}$

Business figure

Table 2.

importance of the service offering; low service complexity), and the service turnover (ST) is lower than the product turnover. In this case, financial performance $(\mathrm{FP})$ improves in terms of sales, while no effect is observed in terms of profitability. Li et al. (2018), Lexutt (2020), Sousa and Da Silveira (2019) and Yan et al. (2019) argue that managerial service orientation (MSO) and a separate service business unit (OS) are necessary conditions to improve sales. Li et al. (2018) contend that the lack of improvements in profitability is likely due to the additional costs of adding a service business, which compensates for the additional sales. Bustinza et al. (2015) suggest that it might be profitable to outsource the provision of basic services to outside suppliers. In addition, Visnjic Kastalli and Van Looy (2013) show that a low servitization level can also be positively related with high nonfinancial performance (NFP), customer satisfaction in particular. They argue that even if the service portfolio consists of 
Conceptual dimensions

Construct; indicator and indicator type

Formula/example

Financial performance $(\mathrm{FP})$

Financial performance level measures (FP)

Company profitability

Mixed; business figure (objective) or Likert scale (subjective)

Profits

Profits growth

Profits

Return on Sales

Profits growth in the last $n$ years

Business figure

Pre-tax per-capita profit

Tobin's $Q$

Return on Investment

Return on equity before taxes

Return on equity net income

Return on Assets

Operating profits/net sales

Categorical

Bankruptcy

Profits/n. employees

Total market value of firm/total asset value of firm

Current value of investment - Cost of investment/Cost of investment

Profits/net assets

Net profits/net assets

Net income/total assets

Service-based financial performance

Mixed; business figure (objective) or Likert scale (subjective)

Service sales growth

Stability of the cash flows over time

Service sales growth in the last $n$ years

"Our cash flows are constant over time."

Product-based financial performance

Mixed; business figure (objective) or Likert scale (subjective)

Product sales

1 - Share of revenue from service

Non-financial performance (NFP)

Non-financial indicators of performance level (NFP)

Manufacturing performance

Business figure (objective) or Likert scale (subjective)

Operational costs

Operational efficiency

Service-based nonfinancial performance

Multi-item or single-item Likert scale

Service quality

Service innovation

Service value for customer's business

Fulfillment of customer expectations

Fulfillment of customer needs

Product-based nonfinancial performance

Multi-item or single-item Likert scale

Product quality

Product innovation

Market performance

Business figure (objective) or Likert scale (subjective)

Market share/growth in reference industry

Market share/growth in other industries

Multi-item or single-item Likert scale

Competitive advantage

Customer relationships

Multi-item or single-item Likert scale

Customer satisfaction

Customer loyalty

Our customers are highly satisfied
Our company is more competitive than its competitors

"Our operational costs are lower than industry competitors."

"Our operational efficiency is higher than industry competitors."

The quality of our services is high

Our service innovation activities are effective

Our services add significant value to our customers' business

Our services exceed our customers' expectations

Our services fulfill our customers' needs

The quality of our products is high

Our product innovation activities are effective

Our market share in our reference industry has increased over the last $n$ years Our market share in other industries has increased over the last $n$ years

Table 3.

Measurement

framework for the

performance impact of

Our customers are very loyal to our business servitization 


\section{IJOPM 41,5}

530
Table 4.

Configurational analysis of the research linking the level of servitization and performance impacts. Identified abstract concepts are crossed, and the identified relationships stated in the right column
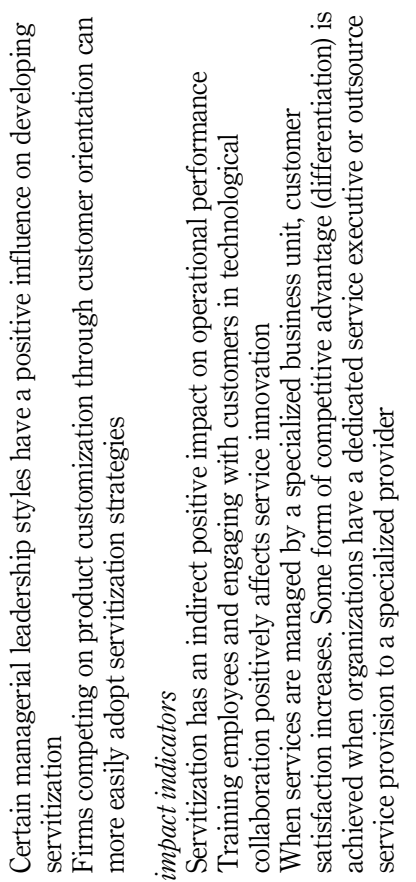

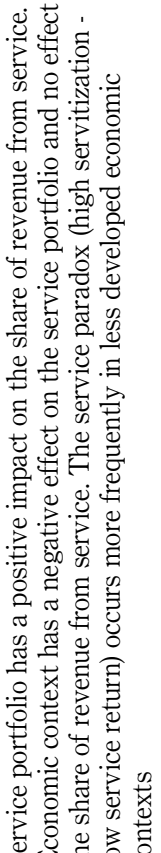

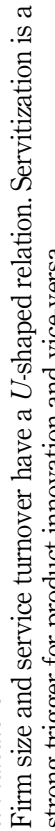

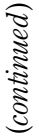

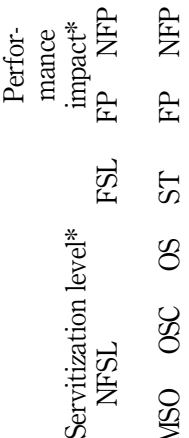

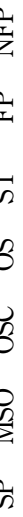

(⿸丆口

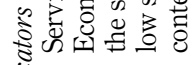

క

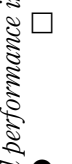

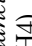

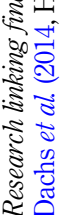




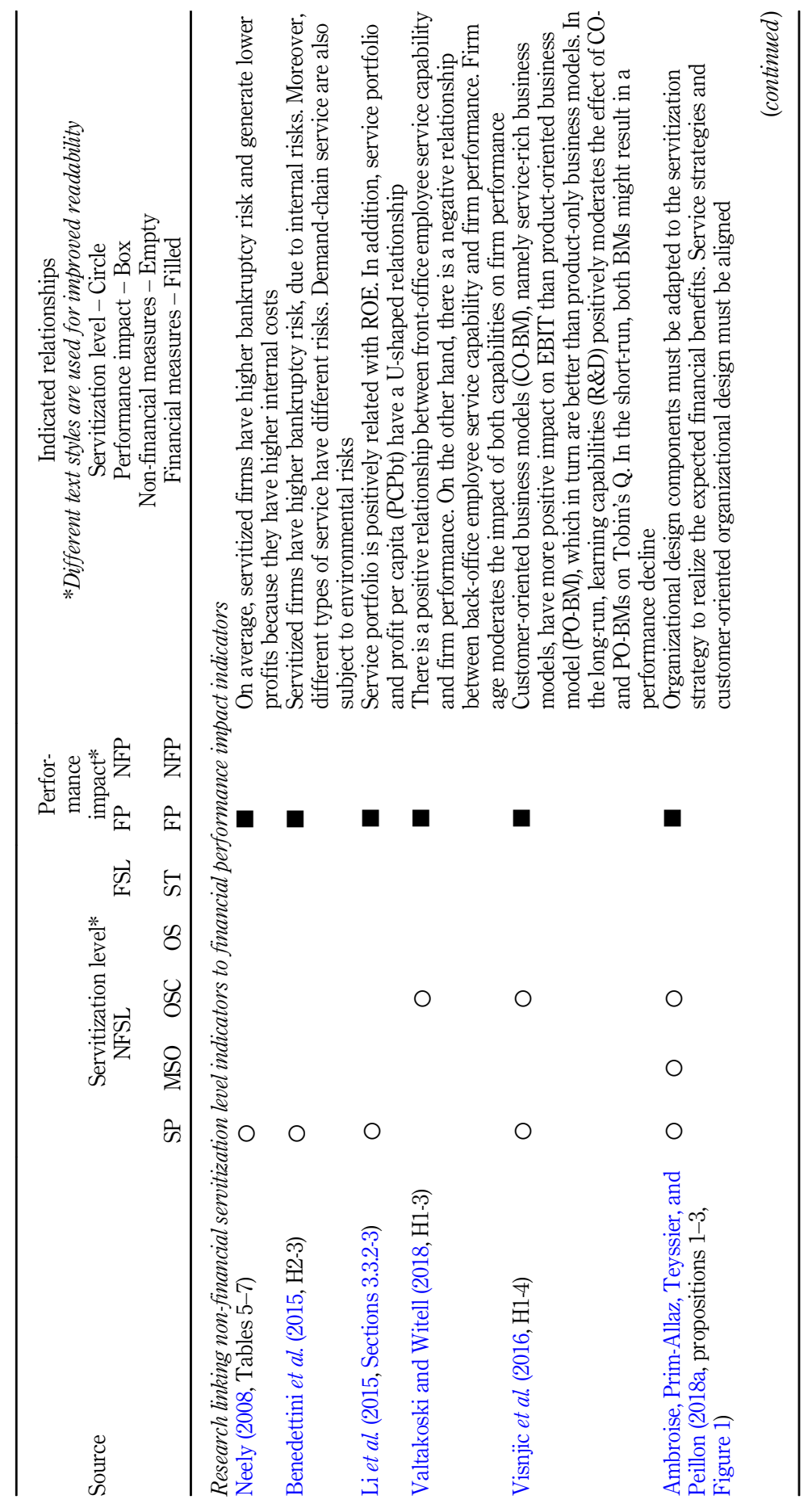

Explaining the servitization paradox

531

Table 4. 


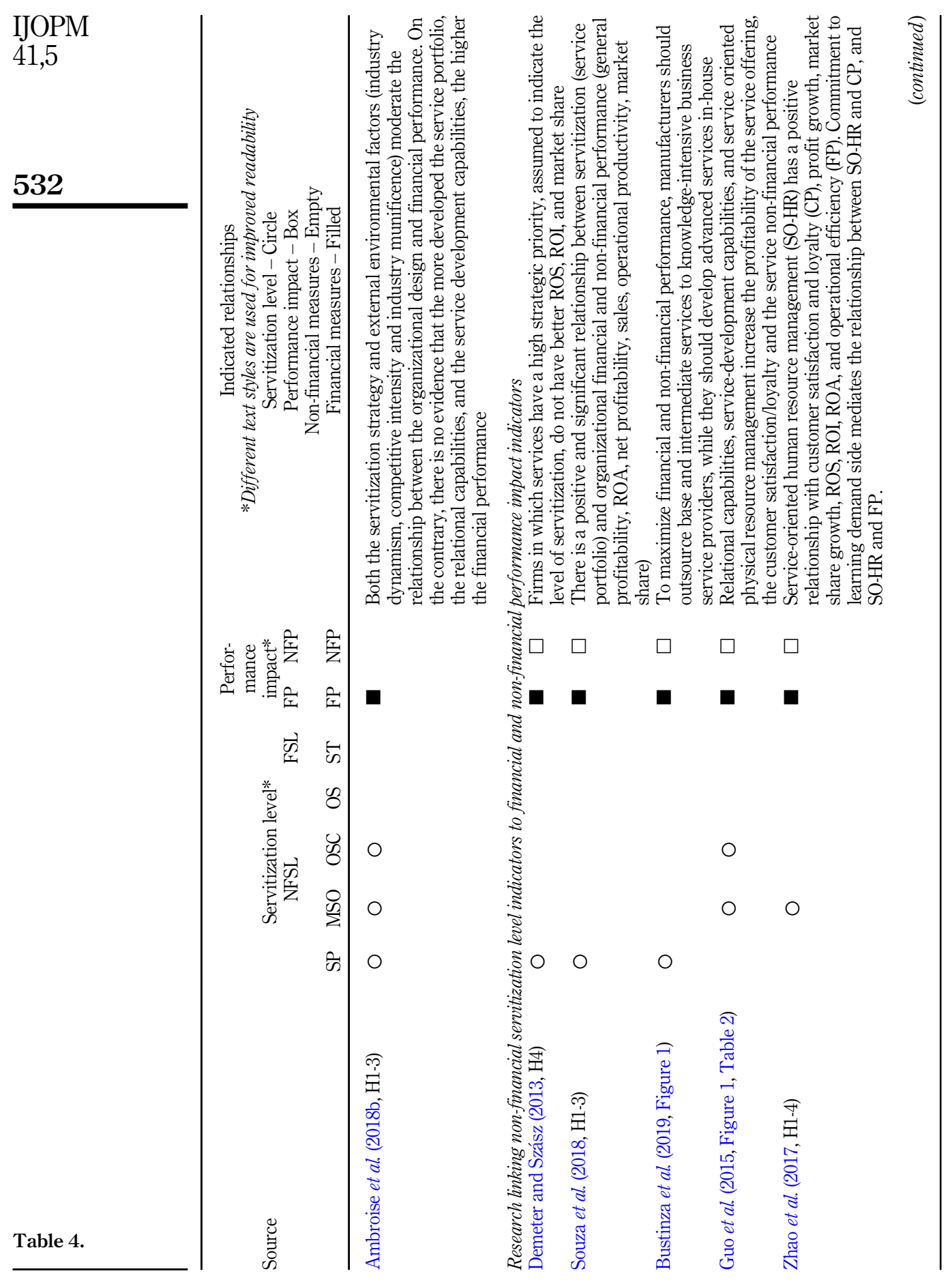




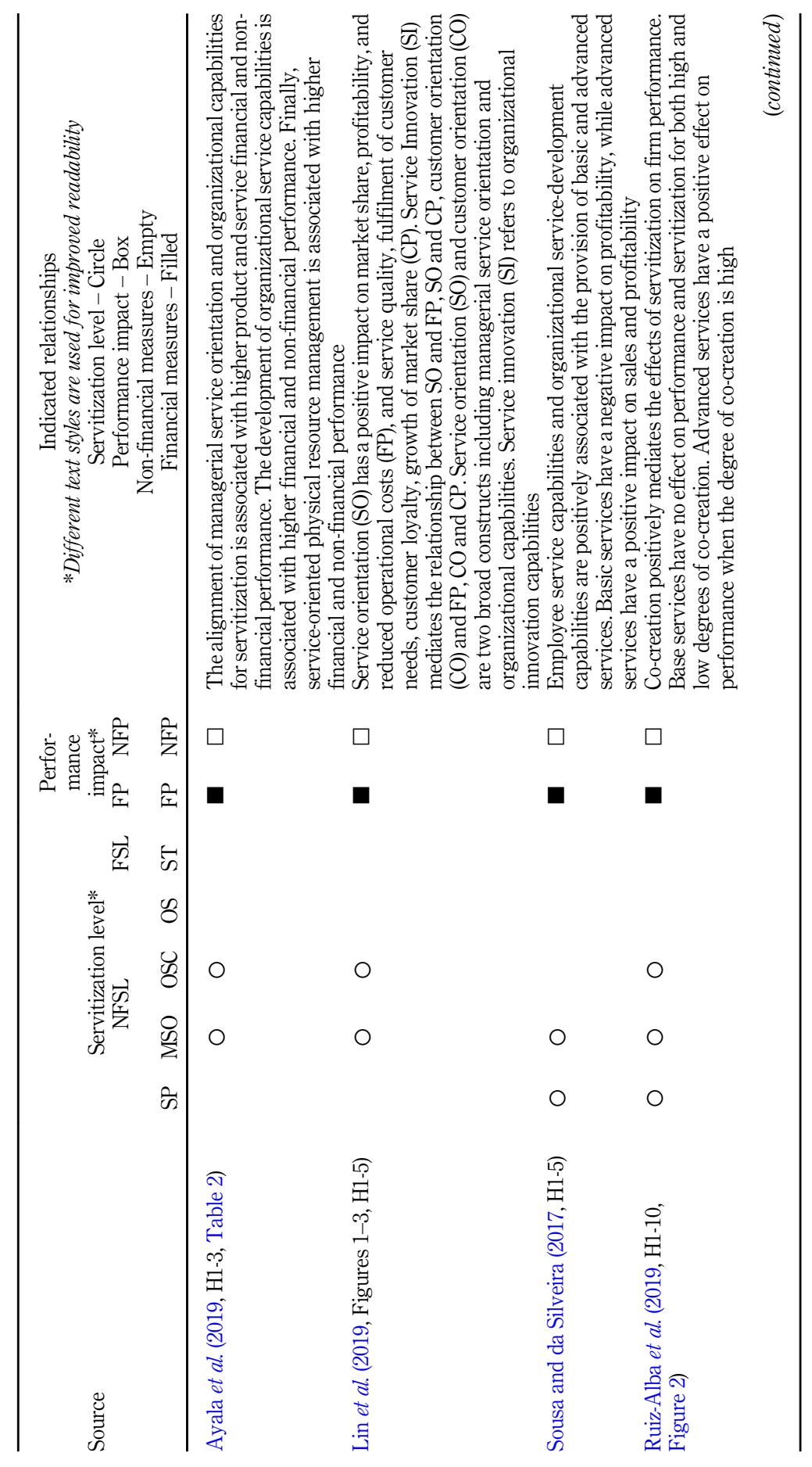

Explaining the servitization paradox

533

Table 4. 


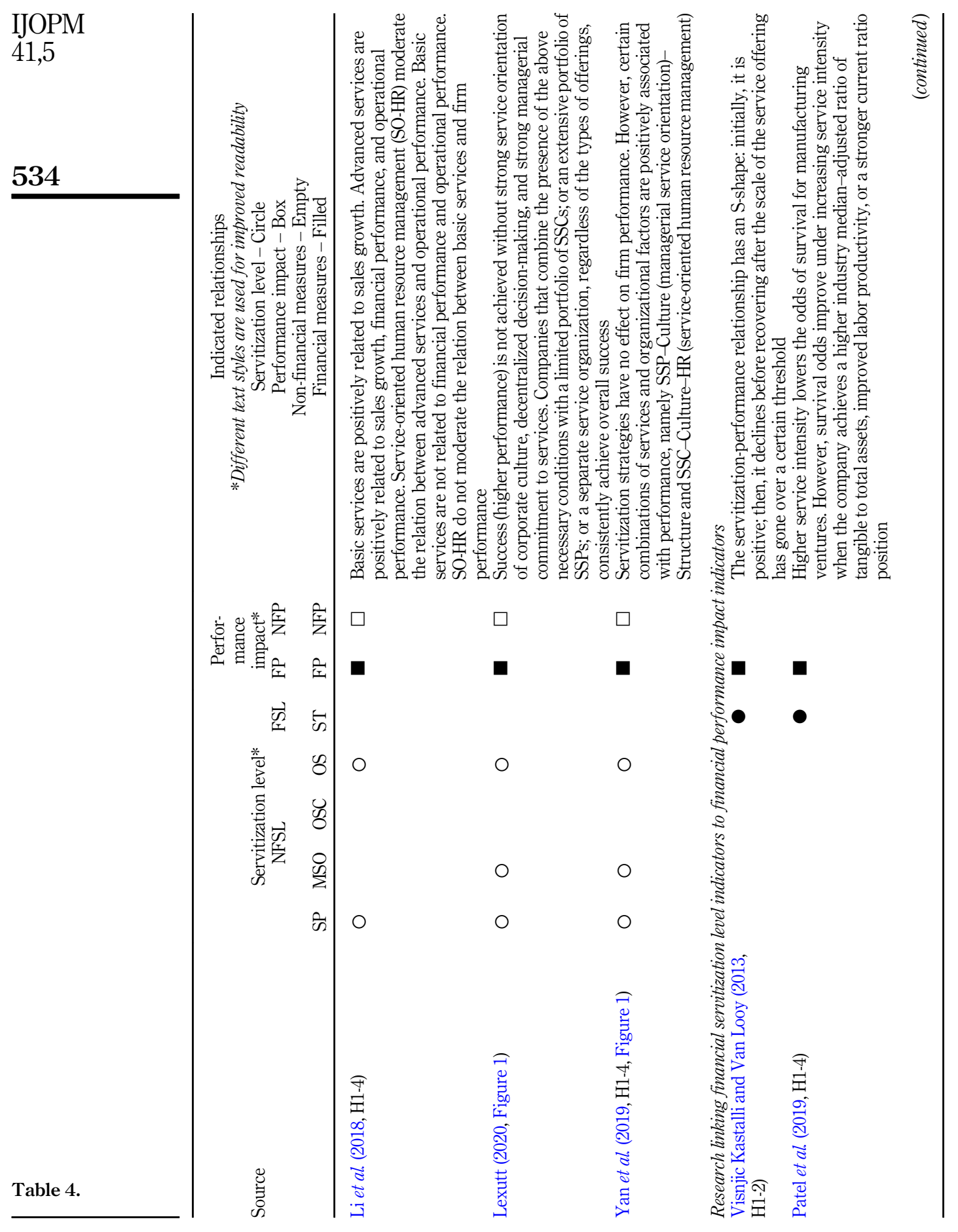




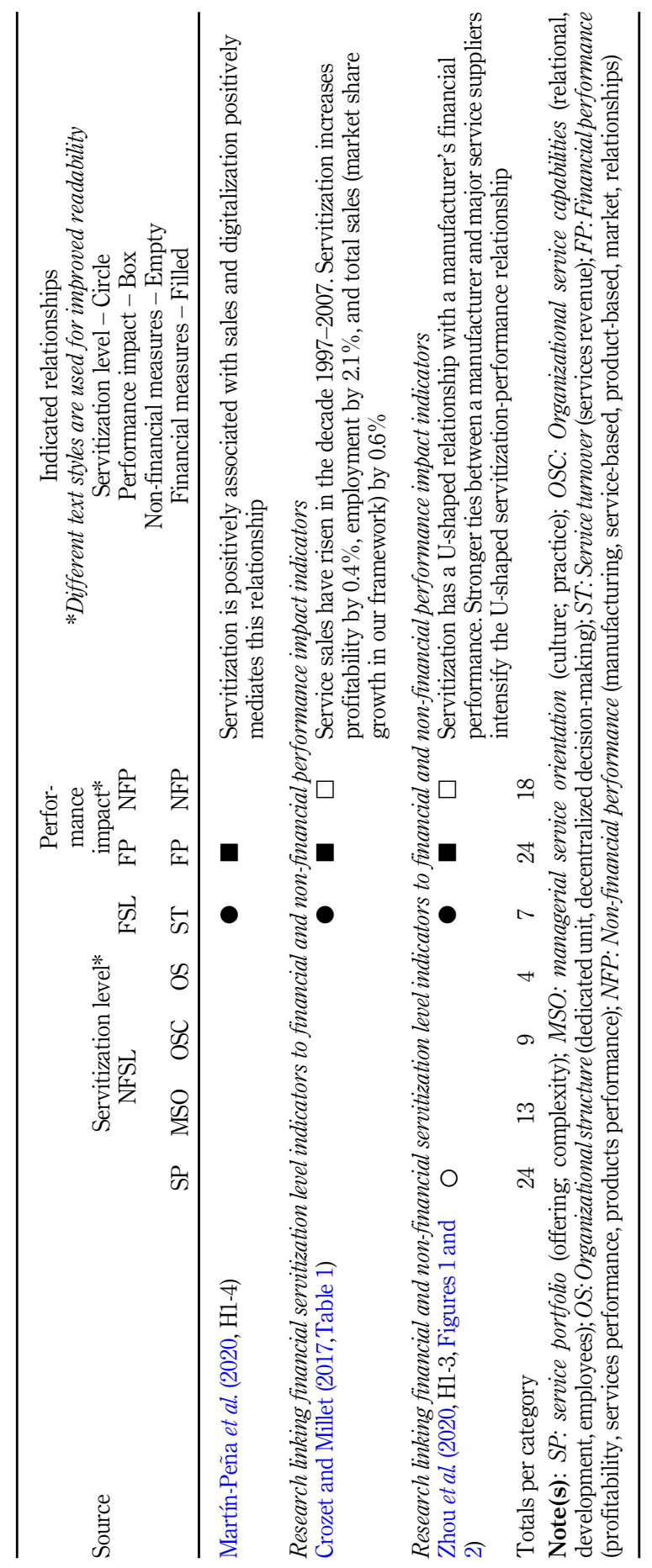

Explaining the servitization paradox

535

Table 4 
IJOPM

41,5

only elementary services, customer proximity increases, and this has a positive effect on customer satisfaction.

The relationship between servitization and performance is different when the level of servitization is intermediate. Visnjic Kastalli and Van Looy (2013) have found that when the scale of service activities (scale and scope of service offering and service turnover in the language of the framework) is at an intermediate level, there is an inflection point in the servitization-performance relationship, which is nonetheless increasing. Li et al. (2015) have instead found it to be a minimum point in the relationship between service portfolio (SP) and profitability. Neu and Brown (2005), Neely (2008) and Benedettini et al. (2015) have shown that there is a point in which the costs of developing new internal resources to support the new business strategy outweigh the benefits. They argue that the negative relationship between servitization and profitability, which is sometimes observed, is explained by the difficulties in changing organizational direction and focus. This combined evidence prompts the conjecture that in going from low to high level of servitization there is a stage in which the servitizationperformance relationship is negative and the risks for the firm are highest.

When the level of servitization is high, the portfolio of service offerings (SO) consists of services such as preventive maintenance and consulting. Often, the capability of the products themselves is offered as a service and customers pay for specific outcomes. In this stage, radical transformation efforts are required, including the refocusing of the entire organization (Brax, 2005; Biege et al., 2012; Baines et al., 2017; Ziaee Bigdeli et al., 2018a). Consequently, managerial service orientation (MSO), organizational capabilities (OC) and structure (OS) play a key role (Lexutt, 2020). In particular, MSO must be high for a positive impact on financial performance (FP) (sales and profitability) to be realized (Sousa and Da Silveira, 2017; Li et al., 2018). High levels of MSO are also required for the impact of servitization on a number of other financial and nonfinancial performance constructs and indicators to be positive. These are customer satisfaction and loyalty, return on investment, return on assets and sales growth (Zhao et al., 2017; Li et al., 2018; Ayala et al., 2019; Frank et al., 2019; Yan et al., 2019). Furthermore, when organizations have a dedicated service executive (OS) or outsource the service provision to specialized providers, performance improves in terms of differentiation and customer satisfaction (Bustinza et al., 2015). Finally, high relational capabilities (OC) are positively correlated with the firm's profitability, sales and competitive advantage (Ruiz-Alba et al., 2019).

\section{Discussion}

\subsection{Theoretical conclusions: a configurational theory of servitization and its performance impact}

There are a number of reasons underlying the reported mixed results in Table 4. First, as multiple ways to servitize exist, each with different impacts on performance, the performance impact of servitization depends on the characteristics of the cases examined (Benedettini et al., 2017; Fliess and Lexutt, 2019). Second, as both servitization and performance are multidimensional concepts, numerous combinations of these dimensions exist, which further multiplies the number of possible relationships among the dimensions (Sousa and Da Silveira, 2017; Yan et al., 2019). Multidimensionality, as can be seen, also generates a lack of agreement on how to measure servitization and its performance impact, which can lead to inconsistencies among analogous studies (Lexutt, 2020). Finally, despite servitization and performance being multidimensional concepts, there is a tendency to measure both through one-dimensional measures, resulting in a partial and, hence, biased picture of their relationship (Wang et al., 2018; Calabrese et al., 2019).

Figure 2 summarizes on a bidimensional graph the main results from the analysis in Table 4. The figure shows the servitization-performance relationship on an $x-y$ plane. The servitization-performance relationship is in-between an S-shaped and a U-shaped curve, according to the findings of Li et al. (2015) and Visnjic Kastalli and Van Looy (2013). The 
servitization-performance relationship is generally positive when the servitization level is low. Afterward, it declines and servitization can sometimes lead to bankruptcy (dashed line), as reported by Benedettini et al. $(2015,2017)$. Then, the relationship rebounds and the performance can be higher than before (Sousa and Da Silveira, 2017; Li et al., 2018; Yan et al., 2019).

The configurations in Table 5 outline the three main propositions that summarize the many-to-many relationships among the various servitization level and performance impact concepts, constructs and indicators in the surveyed literature. As summarized in the table, there is not just a single "servitization-performance relationship". Rather, there are many relationships among the various variables. These relationships are different at different servitization levels. As also shown in Figure 2, the configurations for which the service level is higher (the second and third configurations in Table 5) require an organizational transformation that, if not accomplished, leads to the service financial and organizational paradoxes (Brax, 2005; Gebauer et al., 2005). This explains why speaking of a generic relationship or using different dimensions can create confusion in establishing the effects of servitization on performance. It also demonstrates how a configurational approach can be used to analyze the relationship properly. Next, a thorough discussion on these findings and the configurational theory emerging from the current analysis, is provided.

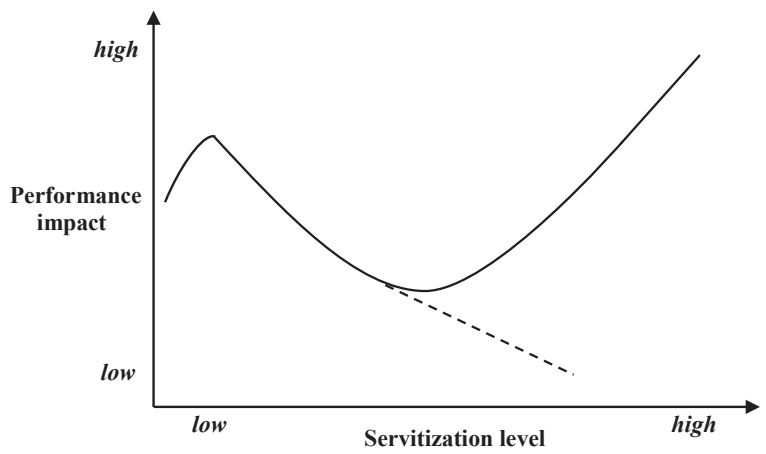

Alternative organizational configurations of servitization and their performance outcome Servitization level indicators

Proposition/ (If) configuration Observed performance impacts

1. Customer support driven servitization Limited service portfolio, low service turnover, separate service organization and high managerial service orientation

2. Tactically driven servitization Average service portfolio and average service turnover

$\rightarrow$

High sales, high customer satisfaction and no effect on profitability

\section{Excellence driven servitization}

Extensive service portfolio, high service turnover, separate service organization, high managerial service orientation and high organizational relational capabilities
Explaining the servitization paradox

537
Figure 2.

Theory of the servitizationperformance relationship

high organizational relational capabilities 
IJOPM

41,5

\subsection{Theoretical contributions}

This study provides two theoretical contributions. First, it clarifies the meaning of both concepts, the level of servitization and its performance impact and proposes a systematic approach to measure both. Second, it analyses the servitization-performance relationship and explains why there are contrasting results about it. The first contribution has been achieved by developing a servitization-performance measurement framework. The second one has been accomplished by using the framework along with configuration theory to interpret previous research findings. Incidentally, a connection between the two contributions is that the different operationalisations of the servitization level and performance impact concepts is one of the causes behind previous contrasting results (Wang et al., 2018), which the framework aims to prevent.

6.2.1 The servitization-performance framework. Performance measurement systems are a critical factor for the success of any organization (Malina and Selto, 2004). Servitized organizations are no exception. Servitization research has disproportionately focused on financial indicators to assess success (Rapaccini, 2015). Fliess and Lexutt (2019) reviewed the literature and found that only $18 \%$ of the articles adopts further performance criteria specific for servitization success. Calabrese et al. (2019) demonstrate that such narrowed focus impairs measuring servitization level effectively. Limiting measurement to service turnover or service types for servitization level and to profitability or sales for performance makes comparison of the results difficult and provides only a partial picture of their relationship (Crozet and Milet, 2017; Sousa and Da Silveira, 2017).

This research contributes to the above drawbacks by recognizing that both the servitization level and performance impact are multidimensional entities that need complex structures to be measured. Specifically, the research adopts the concept-construct-indicator architecture, adapted from Van De Ven (2007), to design a framework for the measurement of the servitization level and performance. This structure allows the identification of all the relevant aspects of servitization and performance to serve further analysis; it facilitates the reconciliation of analogous indicators under homogeneous constructs and concepts; and it makes it easier for researchers and practitioners to adapt the framework to their purposes. Overall, the framework provides a language to researchers and practitioners to measure the level of servitization and its performance impact and to discuss and examine the relationship (Kowalkowski et al., 2017b).

Regarding the level of servitization, this research has recognized that beyond the two most used servitization indicators, i.e. service portfolio and service turnover (Calabrese et al., 2019), several other relevant indicators are needed. Using the concepts and terminology adopted in the current framework, this research shows that three further concepts are needed for comprehensive measuring of the level of servitization: managerial service orientation, organizational capabilities and organizational structure. Managerial service orientation is important because it helps re-shaping the values and behaviors of the organization (Gebauer et al.,2010a) and contributes to nurture the skills required for the service value proposition to be profitable (Penttinen and Palmer, 2007; Gebauer et al., 2010b). Managerial service orientation has been rarely conceptualized for empirical purposes, despite its relevance (Li et al., 2018). This study contributes to its conceptualization and operationalization. As for the organizational capabilities, studies on their effects on performance and their measurement are limited (Ceci and Masini, 2011; Baines et al., 2017; Valtakoski and Witell, 2018). The framework contributes to their identification and measurement, whereas the configurational approach helps clarifying their effect on performance. Finally, the research stresses the importance of including the organizational structure in the assessment of any servitization strategy (Gebauer et al., 2010a).

Analogously to the level of servitization, the framework clarifies the dimensions upon which a successful servitization implementation should be evaluated (Fliess and Lexutt, 2019; Lexutt, 2020). This contribution comes due. As reported in a recent investigation by Wang et al. (2018) extant the empirical literature has neglected some important indicators to assess 
the performance of servitization, especially nonfinancial ones. Accordingly, financial and nonfinancial performances are used as the two broad concepts to sort the various constructs and indicators (Thakkar et al., 2009). In fact, although servitization scholars have long since recognized a number of benefits linked to the adoption of servitization, such as customer satisfaction and loyalty (Pan and Nguyen, 2015) or improved product performance (Raddats et al., 2015), these dimensions have been rarely implemented in empirical studies (Ziaee Bigdeli et al., 2018a; Yan et al., 2019).

6.2.2 The servitization-performance relationship. Speaking about the relationship between servitization and performance, as already noted, multiple studies have reported contrasting findings (e.g. Benedettini et al., 2017; Li et al., 2018; Yan et al., 2019). This paper provides an explanation as to why their relationship changes. Previous literature has shown that different ways to servitize have a different impact on performance; also, how the servitization and the performance are measured affect the empirical results capturing this relationship (Wang et al., 2018; Lexutt, 2020). The current analysis discovers that also what is measured as the "level" and the "performance" plays a major role, and researchers must carefully select the subdimensions to measure these multidimensional concepts. The framework clarifies how to measure the level of servitization and its performance impact.

The configuration theory, applied to servitization (Forkmann et al., 2017; Kohtamäki et al., 2019; Sjödin et al., 2019; Yan et al., 2019; Lexutt, 2020), explains why the servitizationperformance relationship changes according to what is measured. Key to the explanation is the notion of equifinality, i.e. in general terms, the assumption that multiple configurations of different elements lead to the same result (Ragin, 2009). If the elements are taken to be the concepts, constructs or indicators in the framework, the contribution of the theory is clear. The servitization-performance relationship can be either good or bad according to the configurations of the servitization and the performance elements measured in the different studies. When these configurations are taken into account, the results clearly show that no contrasting finding exists. Some ways to servitize have a positive impact on some performance aspects; some have not. There is no general servitization-performance relationship. Rather, there are a number of separate cases or positions to be discussed.

The results are intriguingly connected with early theorizing on the dynamics of the servitization-performance relationship (Mathieu, 2001b) and the observed paradoxes of servitization (Brax, 2005; Gebauer et al., 2005). Note that these studies were not included in the article dataset collected for the SRL as they do not use the term "servitization" which was required to be included in the sample and became commonly accepted in publications later.

The current analysis validates and elaborates previous theorizing on the financial and organizational service paradoxes (Brax, 2005; Gebauer et al., 2005). Mathieu (2001b) labels such costs as "political" and "strategic", which seems appropriate against current findings. A configurational approach shows that the relationship between the level of servitization and firm performance cannot be explained by means of service types and profitability alone. When multiple configurations are accounted for, the paradoxes result for only some of them. In particular, this research has shown that the most relevant factors accounting for the financial service paradox are related to the changes occurring with servitization; the financial service paradox is therefore an organizational transformation paradox (Brax, 2005). Organizational design components must be adapted to the servitization strategy to realize the expected benefits (Ambroise et al., 2018b; Lexutt, 2020). Servitization involves a redefinition of the firm's mission, a redeployment and reconfiguration of organizational resources, capabilities and structures, and a renewal of organizational routines, shared norms and values (Kindström and Kowalkowski, 2014; Kowalkowski et al., 2017a). A failure to accomplish these transformations does not lead to success (Lexutt, 2020). 
IJOPM

41,5

\section{0}

\subsection{Managerial contributions}

Well-designed measurement systems empower managers to make better decisions. With the framework managers can sharpen their understanding and implement firm-specific measurement systems to evaluate the intensity of their firm's ongoing service-oriented transformation and the resulting performance. Regarding the servitization-performance relationship, this paper has shown that managers should pay attention to the alignment between their firm's organizational capabilities and structure and the service portfolio they intend to pursue (Yan et al., 2019; Lexutt, 2020). In addition, managers should be aware that certain environmental factors, such as industry competitiveness and economic context (Szász et al., 2017; Ambroise et al., 2018b), moderate the relationship between the level of servitization and its performance impact.

Managers should also know that, as the current analysis demonstrates, a high level of servitization is more profitable than a low one. However, this comes to the price that the alignment issues highlighted above play a major role when the servitization level is high, making them more challenging (Eggert et al., 2014; Li et al., 2018). Managers of small and medium sized firms can mitigate the risks of increasing the service offering, without giving up the benefits, by outsourcing. The effect of outsourcing to service partners is to intensify the Ushaped servitization-performance relationship, i.e. to reduce the negative effects of servitization throughout the transformation (Zhou et al., 2020). This has proven to be an effective strategy, especially at the beginning of the transformation, when the service offering is still limited and the firm has not yet developed the required capabilities (Bustinza et al., 2019). Alternatively, managers that do have the resources should consider creating a separate service organization and adopting a participative, human-oriented leadership style (Bustinza et al., 2015; Kim and Toya, 2019). Recent empirical research (Kohtamäki et al., 2020) suggests further ways for managers to resolve various tensions within the servitization paradox.

\subsection{Limitations and future research}

This research has shown that the puzzling servitization-performance relationship can be explained by adopting a configurational approach (Forkmann et al., 2017; Kohtamäki et al., 2019; Sjödin et al., 2019; Yan et al., 2019; Lexutt, 2020). Various configurations have been presented. Future research should investigate new configurations by adding new elements. Among those elements, the roles of so-called moderators such as manufacturing and learning capabilities, firm size and age, industry type and conditions, and economic context have been barely touched upon so far, so they must be investigated more in depth (Szász et al., 2017; Ambroise et al., 2018a; Li et al., 2018; Valtakoski and Witell, 2018; Ayala et al., 2019; Patel et al., 2019). In addition, configurations including external service providers should be studied systematically. So far, their role seems to be positive (Bustinza et al., 2019; Zhou et al., 2020), yet more evidence is necessary to understand under which circumstances external suppliers can be safely involved in the servitization process.

Future research should also investigate the role that time plays in the relationship between servitization and firm performance. Visnjic et al. (2016) have shown that in the short-run any servitization strategy can cause financial distress, while in the long-run different strategies achieve different results. Such a claim must be investigated further to see if there are some initial strategies riskier than others are.

Finally, the current research has the limitations of any systematic literature review; although many checks have been performed, the systematic search approaches and snowballing procedures followed may have overlooked certain articles that could add to the analysis, but do not use the terminology adopted here. While it is possible that subsequent studies find indicators that are not included in the framework or propose another rationale to arrange the various indicators in the framework, the aim of this study was not to present an exhaustive portfolio of possible indicators. Instead, this study simplifies the conceptual 
ambiguity around the servitization-performance relationship by developing a clear and robust framework that captures the most relevant and purposeful concepts, constructs and indicators for the two main dimensions.

Despite these limitations, the main contributions of this research are not impaired: servitization and firm performance are multidimensional entities, and their relationship can be understood by analysing the configurations that combine their dimensions. Thus, rather than seeking to expand the framework with additional indicators (which have been considered marginal and therefore have been excluded in the current work), scholars are servitization paradox encouraged to take advantage of the increased conceptual clarity by implementing the framework in further research which empirically examines the various contexts and configuration "cases" of servitization.

\section{References}

Ambroise, L., Prim-Allaz, I. and Teyssier, C. (2018a), "Financial performance of servitized manufacturing firms: a configuration issue between servitization strategies and customeroriented organizational design”, Industrial Marketing Management, Vol. 71, pp. 54-68, doi: 10. 1016/j.indmarman.2017.11.007.

Ambroise, L., Prim-Allaz, I., Teyssier, C. and Peillon, S. (2018b), "The environment-strategy-structure fit and performance of industrial servitized smes", Journal of Service Management, Vol. 29 No. 2, pp. 301-328, doi: 10.1108/JOSM-10-2016-0276.

Ayala, N.F., Gerstlberger, W. and Frank, A.G. (2019), "Managing servitization in product companies: the moderating role of service suppliers", International Journal of Operations and Production Management, Vol. 39 No. 1, pp. 43-74, doi: 10.1108/IJOPM-08-2017-0484.

Baines, T. and Lightfoot, H.W. (2014), "Servitization of the manufacturing firm: Exploring the operations practices and technologies that deliver advanced services", International Journal of Operations and Production Management, Vol. 34 No. 1, pp. 2-35, doi: 10.1108/IJOPM-02-2012-0086.

Baines, T., Lightfoot, H., Benedettini, O. and Kay, J.M. (2009a), "The servitization of manufacturing: a review of literature and reflection on future challenges", Journal of Manufacturing Technology Management, Vol. 20 No. 5, pp. 547-567, doi: 10.1108/17410380910960984.

Baines, T., Lightfoot, H.W., Peppard, J., Johnson, M., Tiwari, A., Shehab, E. and Swink, M. (2009b), "Towards an operations strategy for product-centric servitization", International Journal of Operations and Production Management, Vol. 29 No. 5, pp. 494-519, doi: 10.1108/ 01443570910953603.

Baines, T., Ziaee Bigdeli, A., Bustinza, O.F., Shi, V.G., Baldwin, J. and Ridgway, K. (2017), "Servitization: revisiting the state-of-the-art and research priorities", International Journal of Operations and Production Management, Vol. 37 No. 2, pp. 256-278, doi: 10.1108/IJOPM-06-2015-0312.

Baines, T., Ziaee Bigdeli, A., Sousa, R. and Schroeder, A. (2020), "Framing the servitization transformation process: a model to understand and facilitate the servitization journey", International Journal of Production Economics, Vol. 221, 107463, doi: 10.1016/j.ijpe.2019.07.036.

Benedettini, O., Neely, A. and Swink, M. (2015), "Why do servitized firms fail? A risk-based explanation", International Journal of Operations and Production Management, Vol. 35 No. 6, pp. 946-979, doi: 10.1108/IJOPM-02-2014-0052.

Benedettini, O., Swink, M. and Neely, A. (2017), "Examining the influence of service additions on manufacturing firms' bankruptcy likelihood”, Industrial Marketing Management, Vol. 60, pp. 112-125, doi: 10.1016/j.indmarman.2016.04.011.

Biege, S., Lay, G. and Buschak, D. (2012), "Mapping service processes in manufacturing companies: industrial service blueprinting", International Journal of Operations and Production Management, Vol. 32 No. 8, pp. 932-957.

Brax, S.A. (2005), "A manufacturer becoming service provider - challenges and a paradox”, Managing Service Quality, Vol. 15 No. 2, pp. 142-155, doi: 10.1108/09604520510585334. 
IJOPM 41,5

Brax, S.A. and Jonsson, K. (2009), "Developing integrated solution offerings for remote diagnostics: a comparative case study of two manufacturers", International Journal of Operations and Production Management, Vol. 29 No. 5, pp. 539-560, doi: 10.1108/01443570910953621.

Brax, S.A. and Visintin, F. (2017), "Meta-model of servitization: the integrative profiling approach", Industrial Marketing Management, Vol. 60, pp. 17-32, doi: 10.1016/j.indmarman.2016.04.014.

Bustinza, O.F., Bigdeli, A.Z., Baines, T. and Elliot, C. (2015), "Servitization and competitive advantage: the importance of organizational structure and value chain position", Research-Technology Management, Vol. 58 No. 5, pp. 53-60, doi: 10.5437/08956308X5805354.

Bustinza, O.F., Lafuente, E., Rabetino, R., Vaillant, Y. and Vendrell-Herrero, F. (2019), "Make-or-buy configurational approaches in product-service ecosystems and performance", Journal of Business Research, Vol. 104, pp. 393-401, doi: 10.1016/j.jbusres.2019.01.035.

Calabrese, A., Levialdi Ghiron, N., Tiburzi, L., Baines, T. and Ziaee Bigdeli, A. (2019), "The measurement of degree of servitization: literature review and recommendations", Production Planning and Control, Vol. 30 No. 13, pp. 1118-1135, doi: 10.1080/09537287.2019.1592260.

Ceci, F. and Masini, A. (2011), "Balancing specialized and generic capabilities in the provision of integrated solutions", Industrial and Corporate Change, Vol. 20 No. 1, pp. 91-131, doi: 10.1093/ icc/dtq069.

Crozet, M. and Milet, E. (2017), "Should everybody be in services? The effect of servitization on manufacturing firm performance", Journal of Economics and Management Strategy, Vol. 26 No. 4, pp. 820-841, doi: 10.1111/jems.12211.

Dachs, B., Biege, S., Borowiecki, M., Lay, G., Jäger, A. and Schartinger, D. (2014), "Servitisation of european manufacturing: evidence from a large scale database”, The Service Industries Journal, Vol. 34 No. 1, pp. 5-23, doi: 10.1080/02642069.2013.776543.

Demeter, K. and Szász, L. (2013), "Towards solution based thinking: characteristics of servitization at Hungarian manufacturing companies”, Journal for East European Management Studies, Vol. 18 No. 3, pp. 309-335.

Drazin, R. and Van De Ven, A.H. (1985), "Alternative forms of fit in contingency theory", Administrative Science Quarterly, Vol. 30 No. 4, pp. 514-539, doi: 10.2307/2392695.

Eggert, A., Hogreve, J., Ulaga, W. and Muenkhoff, E. (2014), "Revenue and profit implications of industrial service strategies”, Journal of Service Research, Vol. 17 No. 1, pp. 23-39, doi: 10.1177/ 1094670513485823.

Finne, M., Brax, S. and Holmström, J. (2013), "Reversed servitization paths: a case analysis of two manufacturers”, Service Business, Vol. 7 No. 4, pp. 513-537, doi: 10.1007/s11628-013-0182-1.

Fliess, S. and Lexutt, E. (2019), "How to be successful with servitization - guidelines for research and management”, Industrial Marketing Management, Vol. 78, pp. 58-75, doi: 10.1016/j.indmarman. 2017.11.012.

Forkmann, S., Henneberg, S.C., Witell, L. and Kindström, D. (2017), "Driver configurations for successful service infusion”, Journal of Service Research, Vol. 20 No. 3, pp. 275-291, doi: 10.1177/ 1094670517706160.

Frank, A.G., Mendes, G.H.S., Ayala, N.F. and Ghezzi, A. (2019), "Servitization and industry 4.0 convergence in the digital transformation of product firms: a business model innovation perspective", Technological Forecasting and Social Change, Vol. 141, pp. 341-351, doi: 10.1016/j.techfore.2019.01.014.

Gebauer, H. and Putz, F. (2007), "The impact of service offerings on service-related performance outcomes", International Journal of Services Technology and Management, Vol. 8 Nos 2-3, pp. 123-138, doi: 10.1504/IJSTM.2007.012864.

Gebauer, H., Fleisch, E. and Friedli, T. (2005), "Overcoming the service paradox in manufacturing companies”, European Management Journal, Vol. 23 No. 1, pp. 14-26, doi: 10.1016/j.emj.2004.12.006.

Gebauer, H., Edvardsson, B. and Bjurko, M. (2010a), "The impact of service orientation in corporate culture on business performance in manufacturing companies", Journal of Service Management, Vol. 21 No. 2, pp. 237-259, doi: 10.1108/09564231011039303. 
Gebauer, H., Edvardsson, B., Gustafsson, A. and Witell, L. (2010b), "Match or mismatch: strategystructure configurations in the service business of manufacturing companies", Journal of Service Research, Vol. 13 No. 2, pp. 198-215, doi: 10.1177/1094670509353933.

Gebauer, H., Ren, G.J., Valtakoski, A. and Reynoso, J. (2012), "Service-driven manufacturing: provision, evolution and financial impact of services in industrial firms", Journal of Service Management, Vol. 23 No. 1, pp. 120-136, doi: 10.1108/09564231211209005.

Guo, A., Li, Y., Zuo, Z. and Chen, G. (2015), "Influence of organizational elements on manufacturing firms' service-enhancement: an empirical study based on Chinese ICT industry", Technology in Society, Vol. 43, pp. 183-190, doi: 10.1016/j.techsoc.2015.07.003.

Holmström, J., Brax, S.A. and Ala-Risku, T. (2010), "Comparing provider-customer constellations of visibility-based service”, Journal of Service Management, Vol. 21 No. 5, pp. 675-692, doi: 10.1108/ 09564231011079093.

Kim, S. and Toya, K. (2019), "Leadership style required for the transition to servitization in Japan", Journal of Manufacturing Technology Management, Vol. 30 No. 2, pp. 335-352, doi: 10.1108/ JMTM-02-2018-0034.

Kindström, D. and Kowalkowski, C. (2014), "Service innovation in product-centric firms: a multidimensional business model perspective", Journal of Business and Industrial Marketing, Vol. 29 No. 2, pp. 96-111, doi: 10.1108/JBIM-08-2013-0165.

Kohtamäki, M., Henneberg, S.C., Martinez, V., Kimita, K. and Gebauer, H. (2019), “A configurational approach to servitization: review and research directions", Service Science, Vol. 11 No. 3, pp. 213-240, doi: 10.1287/serv.2019.0245.

Kohtamäki, M., Einola, S. and Rabetino, R. (2020), "Exploring servitization through the paradox lens: coping practices in servitization", International Journal of Production Economics, Vol. 226, 107619, doi: 10.1016/j.ijpe.2020.107619.

Kowalkowski, C., Gebauer, H., Kamp, B. and Parry, G. (2017a), "Servitization and deservitization: overview, concepts, and definitions", Industrial Marketing Management, Vol. 60, pp. 4-10, doi: 10.1016/j.indmarman.2016.12.007.

Kowalkowski, C., Gebauer, H. and Oliva, R. (2017b), "Service growth in product firms: past, present, and future", Industrial Marketing Management, Vol. 60, pp. 82-88, doi: 10.1016/j.indmarman. 2016.10.015.

Laine, T., Paranko, J. and Suomala, P. (2012), "Using a business game concept to enhance servitization: a longitudinal case study", Managing Service Quality, Vol. 22 No. 5, pp. 428-446.

Lexutt, E. (2020), "Different roads to servitization success - a configurational analysis of financial and non-financial service performance", Industrial Marketing Management, Vol. 84, pp. 105-125, doi: 10.1016/j.indmarman.2019.06.004.

Li, J.H., Lin, L., Chen, D.P. and Ma, L.Y. (2015), “An empirical study of servitization paradox in China”, Journal of High Technology Management Research, Vol. 26 No. 1, pp. 66-76, doi: 10.1016/j.hitech. 2015.04.007.

Li, H., Tian, G. and Tian, Y. (2018), "Servitization: its preferred organization and impact on firm performance", Human Systems Management, Vol. 37 No. 2, pp. 181-193, doi: 10.3233/ HSM-18302.

Lin, Y., Luo, J., Ieromonachou, P., Rong, K. and Huang, L. (2019), "Strategic orientation of servitization in manufacturing firms and its impacts on firm performance", Industrial Management and Data Systems, Vol. 119 No. 2, pp. 292-316, doi: 10.1108/IMDS-10-2017-0485.

Luoto, S., Brax, S.A. and Kohtamäki, M. (2017), "Critical meta-analysis of servitization research: Constructing a model-narrative to reveal paradigmatic assumptions", Industrial Marketing Management, Vol. 60, pp. 89-100, doi: 10.1016/j.indmarman.2016.04.008.

Malina, M.A. and Selto, F.H. (2004), "Choice and change of measures in performance measurement models", Management Accounting Research, Vol. 15 No. 4, pp. 441-469, doi: 10.1016/j.mar.2004. 08.002 .

Explaining the servitization paradox 
IJOPM 41,5

\section{4}

Martín-Peña, M.-L., Sánchez-Lopez, J.-M. and Díaz-Garrido, E. (2020), "Servitization and digitalization in manufacturing: the influence on firm performance", Journal of Business and Industrial Marketing, Vol. 35 No. 3, pp. 564-574, doi: 10.1108/JBIM-12-2018-0400.

Martinez, V., Bastl, M., Kingston, J. and Evans, S. (2010), "Challenges in transforming manufacturing organisations into product-service providers", Journal of Manufacturing Technology Management, Vol. 21 No. 4, pp. 449-469, doi: 10.1108/17410381011046571.

Mathieu, V. (2001a), "Product services: from a service supporting the product to a service supporting the client”, Journal of Business and Industrial Marketing, Vol. 16 No. 1, pp. 39-58, doi: 10.1108/ 08858620110364873.

Mathieu, V. (2001b), "Service strategies within the manufacturing sector: benefits, costs and partnership", International Journal of Service Industry Management, Vol. 12 No. 5, pp. 451-475, doi: 10.1108/EUM0000000006093.

Meyer, A.D., Tsui, A.S. and Hinings, C.R. (1993), "Configurational approaches to organizational analysis", Academy of Management Journal, Vol. 36 No. 6, pp. 1175-1195.

Miller, D. (1986), "Configurations of strategy and structure: towards a synthesis", Strategic Management Journal, Vol. 7 No. 3, pp. 233-249, doi: 10.1002/smj.4250070305.

Neely, A. (2008), "Exploring the financial consequences of the servitization of manufacturing", Operations Management Research, Vol. 1 No. 2, pp. 103-118, doi: 10.1007/s12063-009-0015-5.

Neu, W.A. and Brown, S.W. (2005), "Forming successful business-to-business services in goodsdominant firms", Journal of Service Research, Vol. 8 No. 1.

Oliva, R. and Kallenberg, R. (2003), "Managing the transition from products to services", International Journal of Service Industry Management, Vol. 14 No. 2, pp. 160-172, doi: 10.1108/ 09564230310474138.

Oliva, R., Gebauer, H. and Brann, J.M. (2012), "Separate or integrate? Assessing the impact of separation between product and service business on service performance in product manufacturing firms", Journal of Business-To-Business Marketing, Vol. 19 No. 4, pp. 309-334, doi: 10.1080/1051712X.2012.647797.

Opresnik, D. and Taisch, M. (2015), "The value of big data in servitization”, International Journal of Production Economics, Vol. 165, pp. 174-184, doi: 10.1016/j.ijpe.2014.12.036.

Pan, J.-N. and Nguyen, H.T.N. (2015), “Achieving customer satisfaction through product-service systems”, European Journal of Operational Research, Vol. 247 No. 1, pp. 179-190, doi: 10.1016/j. ejor.2015.05.018.

Patel, P.C., Pearce, J.A. and Guedes, M.J. (2019), “The survival benefits of service intensity for new manufacturing ventures: a resource-advantage theory perspective", Journal of Service Research. doi: 10.1177/1094670519838616.

Penttinen, E. and Palmer, J. (2007), "Improving firm positioning through enhanced offerings and buyer-seller relationships", Industrial Marketing Management, Vol. 36 No. 5, pp. 552-564, doi: 10.1016/j.indmarman.2006.02.005.

Rabetino, R., Harmsen, W., Kohtamäki, M. and Sihvonen, J. (2018), "Structuring servitization-related research", International Journal of Operations and Production Management, Vol. 38 No. 2, pp. 350-371, doi: 10.1108/IJOPM-03-2017-0175.

Raddats, C., Burton, J. and Ashman, R. (2015), "Resource configurations for services success in manufacturing companies", Journal of Service Management, Vol. 26 No. 1, pp. 97-116, doi: 10. 1108/JOSM-12-2012-0278.

Raddats, C., Kowalkowski, C., Benedettini, O., Burton, J. and Gebauer, H. (2019), "Servitization: a contemporary thematic review of four major research streams", Industrial Marketing Management, Vol. 83 November 2019, pp. 207-223, doi: 10.1016/j.indmarman.2019.03.015.

Ragin, C.C. (2009), Redesigning Social Inquiry: Fuzzy Sets and Beyond, University of Chicago Press, Chicago. 
Rapaccini, M. (2015), "Pricing strategies of service offerings in manufacturing companies: a literature review and empirical investigation", Production Planning and Control, Vol. 26 Nos 14-15, pp. 1247-1263, doi: 10.1080/09537287.2015.1033495.

Roehrich, J. and Lewis, M. (2014), "Procuring complex performance: implications for exchange governance complexity", International Journal of Operations and Production Management, Vol. 34 No. 2, pp. 221-241, doi: 10.1108/IJOPM-01-2011-0024.

Ruiz-Alba, J.L., Soares, A., Rodríguez-Molina, M.A. and Frías-Jamilena, D.M. (2019), "Servitization strategies from customers' perspective: the moderating role of co-creation", Journal of Business and Industrial Marketing, Vol. 34 No. 3, pp. 628-642, doi: 10.1108/JBIM-02-2017-0028.

Sánchez, D. and Batet, M. (2013), "A semantic similarity method based on information content exploiting multiple ontologies”, Expert Systems with Applications, Vol. 40 No. 4, pp. 1393-1399, doi: 10.1016/j.eswa.2012.08.049.

Santamaría, L., Jesús Nieto, M. and Miles, I. (2012), "Service innovation in manufacturing firms: evidence from Spain”, Technovation, Vol. 32 No. 2, pp. 144-155, doi: 10.1016/j.technovation.2011.08.006.

Sjödin, D., Parida, V. and Kohtamäki, M. (2019), "Relational governance strategies for advanced service provision: multiple paths to superior financial performance in servitization", Journal of Business Research, Vol. 101, pp. 906-915, doi: 10.1016/j.jbusres.2019.02.042.

Sousa, R. and Da Silveira, G.J.C. (2017), "Capability antecedents and performance outcomes of servitization: differences between basic and advanced services", International Journal of Operations and Production Management, Vol. 37 No. 4, pp. 444-467, doi: 10.1108/IJOPM-11-2015-0696.

Sousa, R. and Da Silveira, G.J.C. (2019), "The relationship between servitization and product customization strategies", International Journal of Operations and Production Management, Vol. 39 No. 3, pp. 454-474, doi: 10.1108/IJOPM-03-2018-0177.

Souza, J.W.C., Torres, J.N. and Miyake, D.I. (2018), "Servitization and organizational performance in the machinery and equipment sector", RAE Revista de Administracao de Empresas, Vol. 58 No. 5, pp. 475-493, doi: 10.1590/S0034-759020180504.

Szász, L., Demeter, K., Boer, H. and Cheng, Y. (2017), "Servitization of manufacturing: the effect of economic context”, Journal of Manufacturing Technology Management, Vol. 28 No. 8, pp. 1011-1034, doi: 10.1108/JMTM-11-2016-0166.

Thakkar, J., Kanda, A. and Deshmukh, S.G. (2009), "Supply chain performance measurement framework for small and medium scale enterprises", Benchmarking: An International Journal, Vol. 16 No. 5, pp. 702-723, doi: 10.1108/14635770910987878.

Tranfield, D., Denyer, D. and Smart, P. (2003), "Towards a methodology for developing evidenceinformed management knowledge by means of systematic review", British Journal of Management, Vol. 14, pp. 207-222, doi: 10.1111/1467-8551.00375.

Valtakoski, A. and Witell, L. (2018), "Service capabilities and servitized SME performance: contingency on firm age", International Journal of Operations and Production Management, Vol. 38 No. 4, pp. 1144-1164, doi: 10.1108/IJOPM-06-2016-0328.

Van De Ven, A. (2007), Engaged Scholarship: A Guide for Organizational and Social Research, Oxford University Press, Oxford, New York, NY.

Vandermerwe, S. and Rada, J. (1988), "Servitization of business: adding value by adding services", European Management Journal, Vol. 6 No. 4, pp. 314-324.

Venkatraman, N. (1989a), "The concept of fit in strategy research: toward verbal and statistical correspondence", Academy of Management Review, Vol. 14 No. 3, pp. 423-444, doi: 10.5465/ AMR.1989.4279078.

Venkatraman, N. (1989b), "Strategic orientation of business enterprises: the construct, dimensionality, and measurement", Management Science, Vol. 35 No. 8, pp. 942-962.

Visnjic, I., Wiengarten, F. and Neely, A. (2016), "Only the brave: product innovation, service business model innovation, and their impact on performance", Journal of Product Innovation Management, Vol. 33 No. 1, pp. 36-52, doi: 10.1111/jpim.12254. 
IJOPM 41,5

Visnjic Kastalli, I. and Van Looy, B. (2013), "Servitization: Disentangling the impact of service business model innovation on manufacturing firm performance", Journal of Operations Management, Vol. 31 No. 4, pp. 169-180, doi: 10.1016/j.jom.2013.02.001.

Wang, W., Lai, K.H. and Shou, Y. (2018), "The impact of servitization on firm performance: a metaanalysis”, International Journal of Operations and Production Management, Vol. 38 No. 7, pp. 1562-1588, doi: 10.1108/IJOPM-04-2017-0204.

Ward, P.T., Bickford, D.J. and Leong, G.K. (1996), “Configurations of manufacturing strategy, business strategy, environment and structure”, Journal of Management, Vol. 22 No. 4, pp. 597-626, doi: 10.1177/014920639602200404.

Wilkinson, A., Dainty, A. and Neely, A. (2009), "Changing times and changing timescales: the servitization of manufacturing”, International Journal of Operations and Production Management, Vol. 29 No. 5, doi: 10.1108/ijopm.2009.02429eaa.001.

Yan, K., Cheng, T.C.E., Li, G. and Wei, Z. (2019), "Overcoming the service paradox by leveraging organizational design and cultural factors: a combined configuration and contingency approach”, IEEE Transactions on Engineering Management, Vol. 68 No. 2, April 2021, doi: 10. 1109/TEM.2019.2911105.

Zhang, M., Guo, H. and Zhao, X. (2017), "Effects of social capital on operational performance: impacts of servitisation”, International Journal of Production Research, Vol. 55 No. 15, pp. 4304-4318, doi: 10.1080/00207543.2016.1246764.

Zhao, Y., Zhang, W., Liu, D., Bao, F. and Tian, L. (2017), "Service implementation in manufacturing firms: the role of service-orientated human resource management practices and demand-side search”, Management Decision, Vol. 55 No. 4, pp. 648-661, doi: 10.1108/MD-12-2015-0605.

Zhou, D., Yan, T., Zhao, L. and Guo, J. (2020), "Performance implications of servitization: does a manufacturer's service supply network matter?”, International Journal of Production Economics, Vol. 219, pp. 31-42, doi: 10.1016/j.ijpe.2019.05.019.

Ziaee Bigdeli, A., Baines, T., Bustinza, O.F. and Guang Shi, V. (2017), "Organisational change towards servitization: a theoretical framework”, Competitiveness Review, Vol. 27 No. 1, pp. 12-39, doi: 10. 1108/CR-03-2015-0015.

Ziaee Bigdeli, A., Baines, T., Schroeder, A., Brown, S., Musson, E., Guang Shi, V. and Calabrese, A. (2018a), "Measuring servitization progress and outcome: the case of 'advanced services", Production Planning and Control, Vol. 29 No. 4, pp. 315-332, doi: 10.1080/09537287.2018.1429029.

Ziaee Bigdeli, A., Bustinza, O.F., Vendrell-Herrero, F. and Baines, T. (2018b), "Network positioning and risk perception in servitization: evidence from the UK road transport industry", International Journal of Production Research, Vol. 56 No. 6, pp. 2169-2183, doi: 10.1080/00207543.2017.1341063.

Zou, W., Brax, S.A. and Rajala, R. (2018), "Complexity in product-service systems: review and framework”, Procedia CIRP, Vol. 73, pp. 3-8, doi: 10.1016/j.procir.2018.03.319.

\section{Appendix}

The Appendix is available online for this article.

\section{Corresponding author}

Saara A. Brax can be contacted at: saara.brax@lut.fi

For instructions on how to order reprints of this article, please visit our website:

www.emeraldgrouppublishing.com/licensing/reprints.htm

Or contact us for further details: permissions@emeraldinsight.com 